\title{
Effect of microalgae application on soil algal species diversity, \\ cation exchange capacity and organic matter after herbicide
}

\section{treatments [version 1; peer review: 1 approved, 1 not}

\section{approved]}

\author{
Karin L. Hastings, Lauren E. Smith, Michael L Lindsey, Luke C. Blotsky, \\ Gloria R. Downing, Derex Q. Zellars, Jason K. Downing, Maria Corena-McLeod
}

Integrated Life Sciences Research Complex at Global Organics, Goodyear, AZ, 85338, USA

V1 First published: 14 Nov 2014, 3:281

https://doi.org/10.12688/f1000research.4016.1

Latest published: 14 Nov 2014, 3:281

https://doi.org/10.12688/f1000research.4016.1

\section{Abstract}

Soil microalgae live on small communities that change structure depending on many factors. Some of these factors include soil $\mathrm{pH}$, agricultural practices as well as pesticide and herbicide treatments. The size and activity of these soil microbial communities is an indicator of health, quality and fertility necessary for sustainable agriculture. Methods: A commercial proprietary suspension of microalgae GOgreen ${ }^{\circledR}$ was applied at different concentrations through a center pivot irrigation system to a crop of cultivated corn ( Zea mays) during six months. Experimental plots of 0.5 acres each were planted in four rows. Corn (34,000 plants/acre) was planted in May and harvested in November allowing each plot to be studied for 6 months. In addition, one plot was planted for a second year to study the effects of consecutive planting and harvesting on algae populations in the soil. Soil samples were collected at a depth of 6 inches. Microalgae species identification was based on morphological criteria. Soil analysis included organic matter content (OM), $\mathrm{pH}$ and cation exchange capacity (CEC). Results: Treatment with GOgreen ${ }^{\circledR}$ has significant and measurable positive effects on soil OM content, $\mathrm{CEC}, \mathrm{pH}$ and microalgae species diversity. Conclusions: It was demonstrated through this study that GOgreen ${ }^{\circledR}$ increased diatom numbers and microalgae species diversity showing a restorative effect on soil quality after herbicide treatment in heavily farmed soil. Additionally, GOgreen ${ }^{\circledR}$ lowers the $\mathrm{pH}$ in soils with a pH higher than 7.0 emerging as an economical alternative that is safe for humans and the environment.

\section{Open Peer Review \\ Approval Status $X$ \\ 2 \\ version 1 \\ 14 Nov 2014

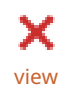 \\ view \\ 1. Matthew A. Bowker, Northern Arizona \\ University, Flagstaff, USA \\ 2. Judith K. Brown, The University of Arizona, \\ Tucson, USA \\ Any reports and responses or comments on the article can be found at the end of the article.}




\section{Keywords}

Microalgae, Cation Exchange Capacity, Organic Matter, Herbicides, Corn, Crops, Fertilizer, Green, GOgreen, pH, restoration, species

diversity, microalgae, soil algae, soil amendments, soil biodiversity.

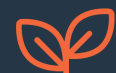

This article is included in the Agriculture, Food

and Nutrition gateway.

Corresponding author: Maria Corena-McLeod (pilarcorena@gmail.com)

Competing interests: No competing interests were disclosed.

Grant information: This study was funded by Global Organics, LLC. Goodyear, AZ, USA.

Copyright: ( $\odot 2014$ Hastings KL et al. This is an open access article distributed under the terms of the Creative Commons Attribution License, which permits unrestricted use, distribution, and reproduction in any medium, provided the original work is properly cited. Data associated with the article are available under the terms of the Creative Commons Zero "No rights reserved" data waiver (CC0 1.0 Public domain dedication).

How to cite this article: Hastings KL, Smith LE, Lindsey ML et al. Effect of microalgae application on soil algal species diversity, cation exchange capacity and organic matter after herbicide treatments [version 1; peer review: 1 approved, 1 not approved] F1000Research 2014, 3:281 https://doi.org/10.12688/f1000research.4016.1

First published: 14 Nov 2014, 3:281 https://doi.org/10.12688/f1000research.4016.1 


\section{Introduction}

The size and activity of soil microbial communities is an indicator of soil health, quality and fertility necessary for sustainable agriculture (Doran \& Parkin, 1994; Kennedy \& Papendick, 1995; Sparling, 1997; Warkentin, 1995). These communities have been classified into eubacteria, cyanobacteria, actinomycetes, archaebacteria, fungi, microalgae, protozoa, viruses, and some nematodes (Paul \& Clark, 1989; Roper \& Gupta, 1995; Sims, 1990). Out of these groups, microalgae perform several important functions for agroecosystems and can also function as a bio-indicator for soil quality.

Four different types of algae are recognized in soil: green (chlorophyta), blue-green (cyanobacteria), yellow-green (xanthophyta), and diatoms (bacillariophyta) (Paul \& Clark, 1989). Soil algae are photoautotrophs. These species do not depend on the organic matter (carbon content) of the soil and play a role as primary colonizers. They produce large amounts of secreted polysaccharides that promote soil aggregation at the surface and they are capable of nitrogen fixation (Goyal, 1997; Zenova et al., 1995). Soil habitats are the most important non-aqueous ecosystems for microalgae (Zenova et al., 1995) where these organisms contribute to soil formation and stability (Metting, 1981). In addition, microalgae contribute to energy and matter flux (Kuzyakhmetov, 1998). Green and bluegreen microalgae populations in upper topsoil can perform valuable services for soil ecosystems (Metting, 1981; Starks et al., 1981) and agriculture (Ruble \& Davis, 1988). One of the major benefits of microalgae is the generation of organic matter from inorganic substances (Alexander, 1977). In addition to providing a food source for other microorganisms, nematodes, and invertebrates, microalgae produce biologically active compounds such as enzymes and ions that can affect other components of soil communities, including plants (Metting, 1981; Zenova et al., 1995).

It has been demonstrated that Gram-negative photosynthetic bacteria play a key role in ecological and plant community succession (Metting, 1981). Primary succession begins in new habitats and it is not influenced by pre-existing communities. Secondary succession follows the disruption of pre-existing communities through external agents such as harvesting, drought or fire. There are few reports on the role that microalgae play in ecological succession. The use of microalgae as fertilizer has recently been suggested (Gaydon et al., 2012). The first objective of this study was to determine the effects of the application of a commercial proprietary suspension of microalgae (Chlorella $s p$. $1 \times 10 \mathrm{e} 3$ cells per $\mathrm{mL}$, Nannochloris $s p$. $1 \times 10 \mathrm{e} 3$ cells per $\mathrm{mL}$, Scenedesmus $s p .1 \times 10 \mathrm{e} 3$ cells per $\mathrm{mL}$ ) formulated to provide nutrients to indigenous soil microorganisms and facilitate microbial density and diversity, as well as to increase soil carbon. The formulation (GOgreen ${ }^{\circledR}$ (Global Organics Group, LLC, Goodyear, AZ) was applied through a center pivot irrigation system in a crop of cultivated corn (Zea mays) on soil algae species diversity after herbicide application and after harvest.

Autogenic and allogenic successions within a particular soil ecosystem are of significant importance to soil communities. In contrast to allogenic succession, caused by abiotic factors such as temperature, light or moisture, autogenic succession is observed when changes in the soil are caused by naturally occurring organisms and plants (Martin \& Hine, 2008). These changes include accumulation of organic matter as well as changes in soil nutrient composition or soil $\mathrm{pH}$. Percent organic matter $(\% \mathrm{OM})$ is a direct measurement of the amount of organic material (animal and plant residues) in the soil (Bot \& Benites, 2005). Organic matter acts as a reservoir for essential nutrients such as nitrogen to be used by the plant or by microbial communities and it is closely related to the Cation Exchange Capacity or CEC of the soil. CEC is directly related to the total amount of cations that a particular soil can hold and in turn it is directly related to the ability of the soil to hold plant nutrients. As OM contributes to cation exchange, the larger the OM content of the soil, the larger the CEC (CUCE, 2007). The secondary objective of this study was to determine the effects of GOgreen ${ }^{\circledR}$ on \%OM and $\mathrm{CEC}$ in experimental plots with different $\mathrm{pH}$ and to compare them with those obtained without GOgreen ${ }^{\circledR}$ treatment.

\section{Materials and methods}

\section{Soil treatments}

Experimental plots of approximately 0.5 acres each were planted in four rows. In order to study the effects of consecutive planting and harvesting on algae populations in the soil, one plot (plot 3) was planted in May 2010 and harvested in October 2010. Treatment for plot 3 is shown in Table 1.

Plots were designated by numbers based on the application rate of GOgreen ${ }^{\circledR}$. Plot 1 (10 oz/acre), plot 2 (8 oz/acre), plot 3 (10 oz/acre) and plot 4 (20 oz/acre). A control plot (plot 5 no GOgreen ${ }^{\circledR}$ ) was also included. Corn (34,000 plants per acre) was planted in May 2011 and harvested in November 2011 allowing each plot to be studied for 6 months. Treatment for all plots is described in detail in Table 2.

\section{Soil analysis}

Soil samples representative from each of the experimental and control plots were taken at a depth of 6 inches immediately after herbicide application (as described in Table 1) following established protocols at the Irrigation Research Foundation (IRF) in Yuma, CO, USA. These samples were labeled pre-treatment. Analysis included organic matter (OM) content, cation exchange capacity (CEC) and $\mathrm{pH}$. Analysis was performed by Midwest Laboratories, Omaha, NE. Details of protocols are available at https://www.midwestlabs.com/ wp-content/uploads/2012/09/139_soil_analysis_methods.pdf.

Each plot received all treatments listed in Table 1 and Table 2 except for the controls. Controls were not treated with GOgreen ${ }^{\circledast}$. Prior to harvest, soil samples were taken from each of the plots (and control). These samples were labeled post-GOgreen ${ }^{\circledR}$. Samples were also taken from each of the plots and controls two months after harvesting. These samples were labeled post-GOgreen ${ }^{\circledR}$ two months. Each plot crossed a region of high soil $\mathrm{pH}$ (8.3) and neutral soil $\mathrm{pH}$ (6.8) and soil samples were taken individually from these regions. Treatments are described in Table 2. After being in use in 2010, plot 3 was again planted in May 2011 and harvested in November 2011 allowing for a year of consecutive corn harvesting and data recording on this plot.

Description of herbicide treatments was relevant to our study because herbicides have been documented to have a detrimental effect on soil algae populations (Kuzyakhmetov, 1998; Zancan et al., 2006). GOgreen ${ }^{\circledR}$ was delivered at the manufacture's recommended application rate through center pivot irrigation before the 
Table 1. Treatment and applications for plot 3 during 2010. Plot size: 4 rows per variety. Planting population: $35,500$. NPK: Nitrogen, Phosphorus and Potassium content.

\begin{tabular}{|c|c|c|c|c|}
\hline Crop/plot info & Treatment(s) & Description & Application & Dates \\
\hline \multirow{2}{*}{$\begin{array}{l}\text { Approximate area: } \\
0.5 \text { acres }\end{array}$} & $\begin{array}{l}\text { Strip-Till: fertilizer } \\
\text { applied }\end{array}$ & $\begin{array}{l}\text { NPK: } \\
\text { 20.5-35.8-0 }\end{array}$ & $\begin{array}{l}10 \text { gallons at } 4 \text { inches seedling height } \\
\text { and } 15 \text { gallons at } 10 \text { inches height }\end{array}$ & 04/09/2010 \\
\hline & $\begin{array}{l}\text { Starter: applied with } \\
\text { tractor }\end{array}$ & $\begin{array}{l}\text { NPK: } \\
\text { 30-40-0-45-0.053 Zn }\end{array}$ & $\begin{array}{l}2 \text { inches to the side and } 2 \text { inches } \\
\text { below the seed at } 18 \text { gal per acre }\end{array}$ & 05/05/2010 \\
\hline \multirow[t]{2}{*}{$\begin{array}{l}\text { Corn planting date } \\
05 / 01 / 2010\end{array}$} & Sprinkler irrigation & $\begin{array}{l}\text { NPK: } \\
28-0-0-5 \mathrm{Zn}\end{array}$ & & $\begin{array}{l}06 / 03 / 2010 \\
06 / 17 / 2010 \\
07 / 10 / 2010 \\
07 / 17 / 2010\end{array}$ \\
\hline & Degree Xtra & Herbicide & $3 \mathrm{qt} / \mathrm{acre}$ & 04/28/2010 \\
\hline \multirow{4}{*}{$\begin{array}{l}\text { Harvest date } \\
10 / 13 / 2010\end{array}$} & Round-Up & Herbicide & 32 oz/acre & 04/28/2010 \\
\hline & Class Act & Herbicide adjuvant & $0.54 \mathrm{qt} / \mathrm{acre}$ & 04/28/2010 \\
\hline & Round-Up & Herbicide & 32 oz/acre & 06/16/2010 \\
\hline & AMS 17 & Herbicide adjuvant & 100 gal. & 06/16/2010 \\
\hline \multirow{2}{*}{$\begin{array}{l}\text { Plots subject to } \\
\text { high winds }\end{array}$} & GOgreen $^{\circledast}$ & $\begin{array}{l}4 \text { weeks } \\
\text { post-emergence }\end{array}$ & 10 oz/acre & 05/30/2010 \\
\hline & GOgreen $^{\circledast}$ & $\begin{array}{l}8 \text { weeks } \\
\text { Post-emergence }\end{array}$ & 10 oz/acre & $06 / 17 / 2010$ \\
\hline
\end{tabular}

Table 2. Treatment and applications for plots 1-4 and control during 2011. Plot size: 4 rows per variety. All plots were divided into high (8.3) and low pH (6.8). Planting population: 34,000. (N/A = not applicable; *second treatment in consecutive years).

\begin{tabular}{|c|c|c|c|c|}
\hline Crop/plot info & Treatment(s) & Description & Application & $\begin{array}{l}\text { Dates } \\
M / D / 2011\end{array}$ \\
\hline \multirow{5}{*}{$\begin{array}{l}\text { Approximate area: } \\
0.5 \text { acres }\end{array}$} & $\begin{array}{l}\text { Strip-Till: fertilizer applied } \\
\text { while strip tilling }\end{array}$ & $\begin{array}{l}\text { NPK to all plots } \\
9-15-0\end{array}$ & $\begin{array}{l}8 \text { gallons at } 4 \text { inches seedling height } \\
\text { and } 13 \text { gallons at } 10 \text { inches height }\end{array}$ & 04/05 \\
\hline & $\begin{array}{l}\text { Starter: applied with } \\
\text { tractor }\end{array}$ & $\begin{array}{l}\text { NPK to all plots } \\
15-20-0-2.0 \text { s- } 0.027 \mathrm{Zn}\end{array}$ & $\begin{array}{l}2 \text { in. to the side and } 2 \text { in. below the } \\
\text { seed at } 18 \text { gal./acre }\end{array}$ & 05/09 \\
\hline & Sprinkler irrigation & $\begin{array}{l}\text { NPK to all plots } \\
32-0-0\end{array}$ & $\begin{array}{l}10 \text { gal./acre } \\
4 \text { gal./acre } \\
4 \text { gal./acre } \\
10 \text { gal./acre } \\
10 \text { gal./acre }\end{array}$ & $\begin{array}{l}06 / 19 \\
06 / 29 \\
07 / 02 \\
07 / 15 \\
07 / 19\end{array}$ \\
\hline & Degree Xtra & Herbicide to all plots & $2.9 \mathrm{qt} / \mathrm{acre}$ & 05/01 \\
\hline & Round-Up & Herbicide to all plots & 32 oz/acre & 05/01 \\
\hline \multirow{3}{*}{$\begin{array}{l}\text { Corn planting date } \\
05 / 09 / 2011\end{array}$} & Synurgize & Glyphosate adjuvant & 1 qt./100 gal of $\mathrm{H} 2 \mathrm{O}$ & $05 / 01$ \\
\hline & $\begin{array}{l}\text { Non-ionic surfactant } \\
\text { (NIS) }\end{array}$ & Herbicide to all plots & $32 \mathrm{oz} / 100 \mathrm{gal} . / \mathrm{acre}$ & $06 / 16$ \\
\hline & Round-Up Weathermax & Herbicide to all plots & 32 oz/acre & $06 / 16$ \\
\hline \multirow{3}{*}{$\begin{array}{l}\text { Harvest date } \\
11 / 30 / 2011\end{array}$} & AMS 17 & Herbicide to all plots & $17 \mathrm{lbs} / 100 \mathrm{gal} . / \mathrm{acre}$ & $06 / 16$ \\
\hline & GOgreen ${ }^{\circledR}$ & To Plot 1 only & 10 oz/acre & $\begin{array}{l}06 / 22 \\
06 / 29\end{array}$ \\
\hline & GOgreen ${ }^{\circledR}$ & To Plot 2 only & 8 oz/acre (half label dosage) & $\begin{array}{l}06 / 22 \\
06 / 29\end{array}$ \\
\hline \multirow[t]{3}{*}{$\begin{array}{l}\text { Plots subject to } \\
\text { high winds }\end{array}$} & GOgreen ${ }^{\circledast}$ & To Plot $3^{*}$ only & 10 oz/acre & $\begin{array}{l}06 / 22 \\
06 / 29 \\
07 / 05\end{array}$ \\
\hline & GOgreen ${ }^{\circledast}$ & To Plot 4 only & 20 oz/acre & $\begin{array}{l}06 / 22 \\
06 / 29 \\
07 / 05\end{array}$ \\
\hline & No GOgreen ${ }^{\circledR}$ & Plot 5 & Control & $\mathrm{N} / \mathrm{A}$ \\
\hline
\end{tabular}


V7 stage of corn plant growth. Soil samples were taken at V5 stage of plant growth as well as $4,6,7$, and 8 weeks after emergence. A final sample was taken at harvest (black layer).

\section{Statistical analysis}

Two-tailed paired difference t-test was used to compare groups pre and post treatment to determine if GOgreen ${ }^{\circledR}$ had an effect on the tested soil parameters. Results of Statistical analysis are shown in Table 4. Statistical analysis was performed using GraphPad Prism software (GraphPad, San Diego, CA, USA).

\section{Algal species identification}

Media and solutions were prepared using reagents from SigmaAldrich (St. Louis, MO) unless otherwise specified. HEPES buffer (50 mM, pH 7.8) was used to prepare Vitamin B12, Biotin and Thiamine solutions. In order to culture algae for identification purposes, 1 gram of soil from each plot, including high and low $\mathrm{pH}$ regions as separate samples, was added to $10 \mathrm{~mL}$ of selective media containing BG-11, Bolds $3 \mathrm{~N}$ and DM and plated using approximately $200 \mu \mathrm{l}$ in Agar plates with the same composition. Plates were prepared using a spread plate method. The media was selective for photosynthetic organisms.

3N Modified Bold's Basal Media (Bold, 1949) was used for enrichment of green, red, and brown algae. Soil water was prepared using an adaptation of E.G. Pringsheim's biphasic soil-water medium (Pringsheim, 1946). Diatom Medium (DM) was used to culture and identify diatoms (Beakes et al., 1988), Proteose medium (PM) was used for yellow-green algae. PM was made by adding proteose peptone to Bristol Medium at a final concentration of $1 \mathrm{~g} / \mathrm{L}$. Bristol medium was prepared according to Bold, (1949). To culture cyanobacteria, BG-11 was used as previously described (Stanier et al., 1971). Cultures were grown at 16:8 under full spectrum grow lights for 4-6 weeks at $22^{\circ} \mathrm{C}$. Algae layers $(1 \mathrm{~mL})$ were collected using a Pasteur pipette and plates of selective medium were inoculated. Colonies were counted and identified through light microscopy using a Labomed LX500 microscope (Labomed, Hicksville, NY) six days dates post-inoculation.

\section{Results}

Results from soil analysis pre-treatment and after GOgreen ${ }^{\circledR}$ treatment at harvest and 2 months post-harvest are shown in Table 3. Plot 2 values are shown prior to plot 1 values as the dose applied in plot 2 was 8 oz./acre vs. $10 \mathrm{oz}$./acre applied in plot 1 . This order facilitated comparison between a one time application of GOgreen ${ }^{\circledR}$ (plot 1) vs. consecutive GOgreen ${ }^{\circledR}$ application (plot 3). Percentages of OM were very low for all plots including the control plot. This is typically observed in soils in the Southwest (USA) (Hargrove \& Luxmore, 1988). Differences in OM and CEC preand post-GOgreen ${ }^{\circledR}$ treatment for each individual plot are shown in Figure $1 \mathrm{~A}$ and $\mathrm{B}$ respectively.

\section{Differences in percent organic matter}

Our results indicate that GOgreen ${ }^{\circledR}$ has a significant effect in the $\mathrm{OM}$ content of soil at both $\mathrm{pH}$ values tested. Although lower OM values were observed prior to harvest in soil treated with GOgreen ${ }^{\circledR}$ with $\mathrm{pH}<8.0$ when compared with the controls (Figure 1A (left)), an increase in OM was observed two months after harvest (Figure 1A (right)). In soil with $\mathrm{pH}>8.0$, GOgreen ${ }^{\circledR} \mathrm{OM}$ content values were higher prior to harvest when compared to those obtained at $\mathrm{pH}<8.0$. In the first group, treatment with GOgreen ${ }^{\circledR}$ at the recommended manufacturer dose (Table 2) appeared to have a positive effect on CEC. Although GOgreen ${ }^{\circledR}$ initially increased the OM content of the soil prior to harvest (Figure 1B (left)) this effect was not sustained two months after harvest (Figure 1B (right)) in this particular soil and/or crop type. It is worth noting that although the control at $\mathrm{pH}<8.0$ did not show any changes in OM over time, the control at $\mathrm{pH}>8.0$ showed a significant decrease in OM (shown as a $*$ in Figure 1B) indicating that other factors independent of GOgreen ${ }^{\circledR}$ application might have played a role in OM content measurements at high $\mathrm{pH}$ values.

\section{Differences in cation exchange capacity}

In terms of CEC, significant differences were observed in CEC two months after harvest when compared to samples collected prior to harvest (Figure 2A and B). It was observed that prior to harvest GOgreen ${ }^{\circledR}$ treatment at the recommended 10 oz./acre increased the $\mathrm{CEC}$ of the soil in the treated plots at $\mathrm{pH}<8.0$. The highest CEC

Table 3. Soil analysis for all plots post-algae treatment. All units in parts per million (ppm) unless otherwise noted. * indicates pre- GOgreen ${ }^{\circledR}$ treatment the previous year. Abbreviations: OM $(\%)=$ Percent Organic Matter, CEC= Cation Exchange Capacity. $\mathrm{L}=\mathrm{pH}<8.0, \mathrm{H}=\mathrm{pH}>8.0$ post $=$ after GOgreen ${ }^{\circledR}$ treatment. Post-2M $=2$ months after harvest.

\begin{tabular}{|l|c|c|c|}
\hline Sample ID & pH & OM (\%) & CEC (meq/100g) \\
\hline Control L & 6.90 & 0.90 & 10.60 \\
\hline Plot 2 L-post & 7.70 & 0.70 & 9.10 \\
\hline Plot 1 L-post & 7.30 & 0.80 & 11.20 \\
\hline Plot 3* L-post & 7.70 & 0.70 & 10.60 \\
\hline Plot 4 L-post & 7.60 & 0.70 & 11.80 \\
\hline Control L post-2M & 7.00 & 0.90 & 8.20 \\
\hline Plot 2 L post-2M & 7.00 & 1.00 & 8.10 \\
\hline Plot 1 L post-2M & 7.20 & 1.10 & 8.00 \\
\hline Plot 3* L post-2M & 6.90 & 1.10 & 8.60 \\
\hline Plot 4 L post-2M & 6.90 & 1.00 & 8.60 \\
\hline Control H-post & 8.20 & 1.00 & 17.60 \\
\hline Plot 2 H-post & 8.30 & 1.00 & 18.30 \\
\hline Plot 1 H-post & 8.20 & 1.10 & 16.50 \\
\hline Plot 3* H-post & 8.30 & 1.30 & 18.40 \\
\hline Plot 4 H-post & 8.10 & 1.10 & 16.30 \\
\hline Control H post-2M & 7.90 & 0.70 & 9.50 \\
\hline Plot 2 H post-2M & 7.80 & 0.80 & 11.50 \\
\hline Plot 1 H post-2M & 7.70 & 0.70 & 7.50 \\
\hline Plot 3* H post-2M & 8.40 & 0.90 & 11.00 \\
\hline Plot 4 H post-2M & 8.30 & 0.80 & 14.30 \\
\hline & & & \\
\hline
\end{tabular}


A.

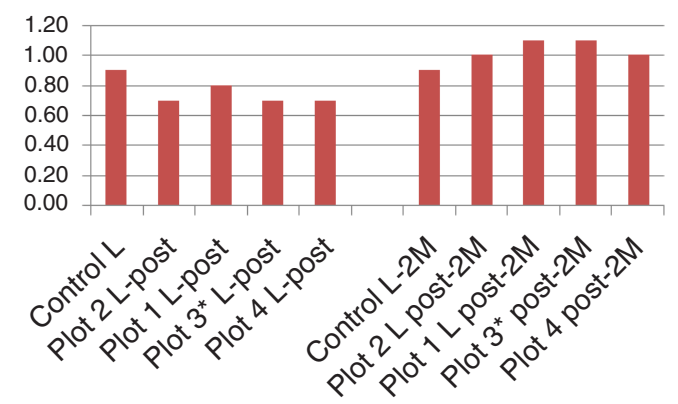

- Organic matter $(\%)$

B.

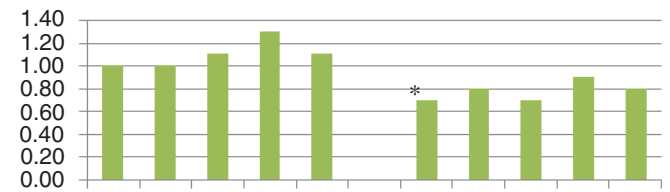

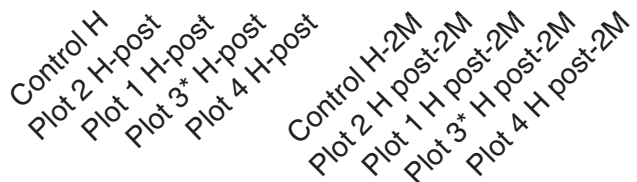

Organic matter (\%)

Figure 1. Differences in percent organic matter (OM) before and after treatment with GOgreen ${ }^{\circledR}$. A. In soil with $\mathrm{pH}<8.0$ (red) a lower OM content when compared to the control was observed. These numbers increased 2 months after harvest as shown to the right. B. Soils with $\mathrm{pH}>8.0$ (green) showed the opposite trend. These changes indicate that treatment with GOgreen ${ }^{\circledast}$ result in changes in OM content in the soil that vary according to $\mathrm{pH}$.

A.

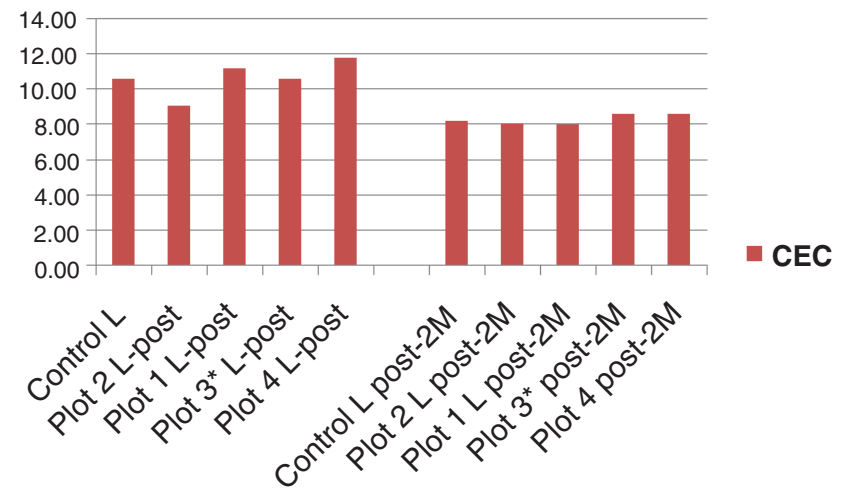

B.
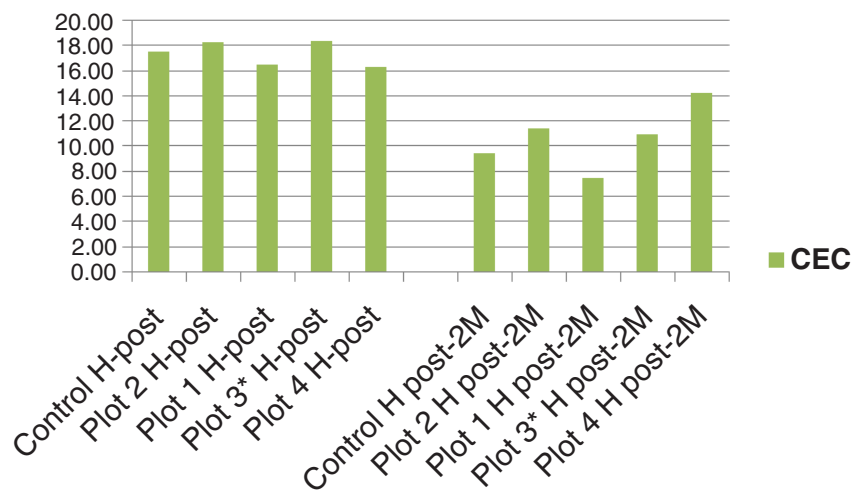

Figure 2. Differences in cation exchange capacity (CEC) in meq/100 $\mathrm{g}$ before and after treatment with GOgreen ${ }^{\circledR}$. A. Areas with $\mathrm{pH}<8.0$ (red) show a lower CEC 2 months after treatment, $\mathbf{B}$. Areas with $\mathrm{pH}>8.0$ (green) show a similar trend with a significantly lower CEC 2 months after harvest. 
obtained prior to harvest was observed at $20 \mathrm{oz}$./acre in the soil samples with $\mathrm{pH}<8.0$. Two months after harvest, the CEC values declined for all plots in this group including the control and the values were uniform. The average CEC for all plots at harvest was $10.6 \mathrm{meq} / 100 \mathrm{~g}$ for the controls at this $\mathrm{pH}$ value and the average for all plots was $10.68 \mathrm{meq} / 100 \mathrm{~g}$ indicating an increase of 0.08 units reflected in a greater ability of the soil to bind and retain ions and nutrients (Table 3). There were no increases observed in CEC in the plots treated with GOgreen ${ }^{\circledR}$ at $\mathrm{pH}>8.0$ prior to harvest. Although the CEC values for the plots in the $\mathrm{pH}>8.0$ group were significantly higher (by about $7 \mathrm{meq} 1 / 100 \mathrm{~g}$ ) when compared to the plots in the $\mathrm{pH}<8.0$ group, two months after harvest, CEC values were also lower than those observed prior to harvest consistent with the CEC values observed for the $\mathrm{pH}<8.0$ group.

Algal species diversity

The effect of GOgreen ${ }^{\circledR}$ was studied in plots before and after application. Total algae counts were grouped as percentages of bluegreen and green algae as well as diatoms. The results are shown in Figure 3 (and Dataset 1).

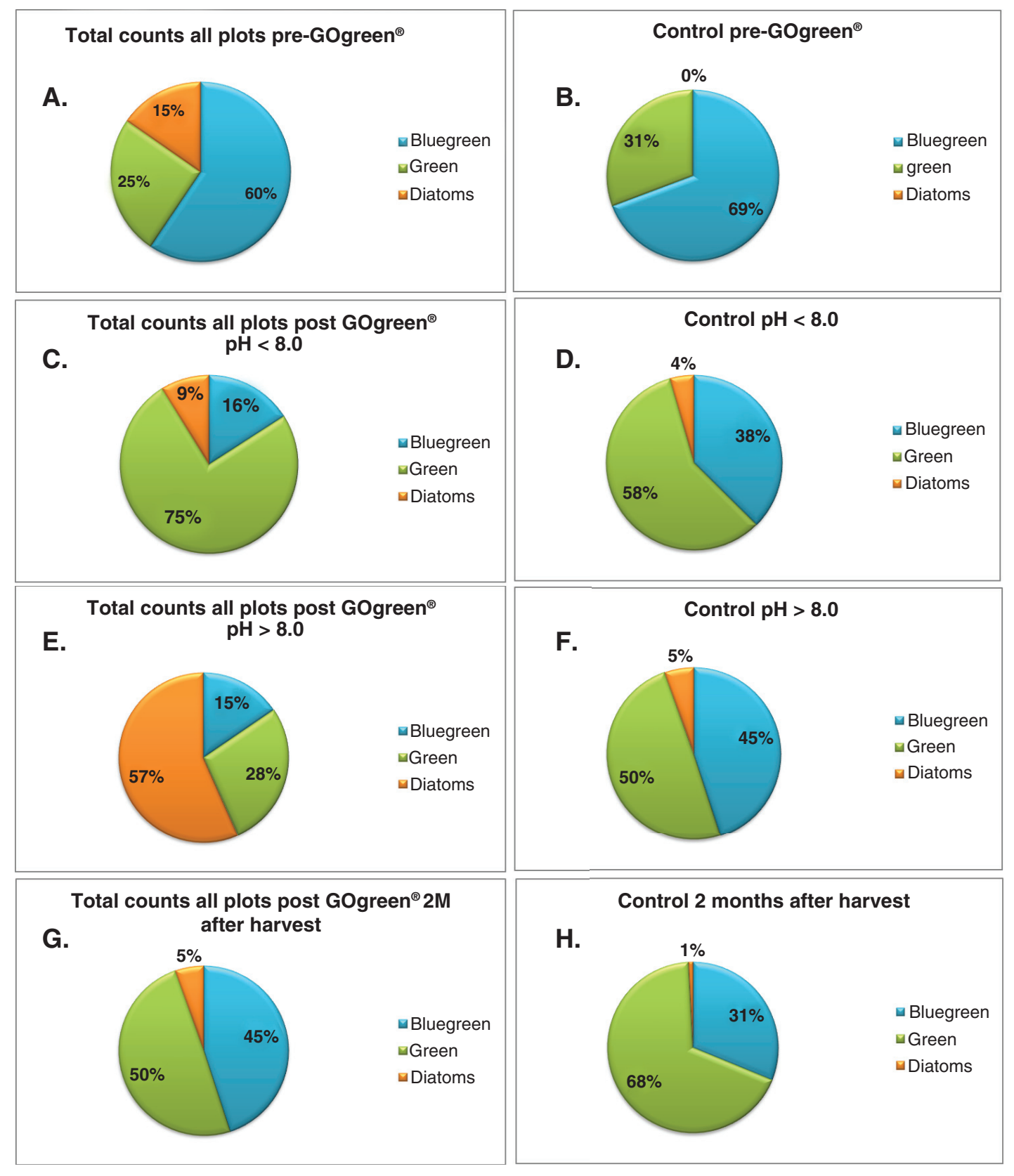

Figure 3. Algal species diversity before and after GOgreen ${ }^{\circledR}$ treatment. Effects of pH in total counts of groups of species. A. Total counts all plots pre-treatment. B. Control pre-treatment. C. Total counts all plots $\mathrm{pH}<8.0$. D. Control $\mathrm{pH}<8.0$. E. Total counts all plots $\mathrm{pH}>8.0$. F. Control pH > 8.0. G. Total counts all plots 2 months after harvest. H. Control 2 months after harvest. Please see Dataset 1 for the raw data. 
Table 4. Statistical analysis of group comparisons. Given soil heterogeneity plots were grouped in pre and post treatment groups. Paired Difference t-test analysis was chosen given the small number of samples to analyze. Stedv (Standard Deviation of the Population), $\mathrm{df}=$ degrees of freedom.

\begin{tabular}{|c|c|c|}
\hline pH comparison & Group 1 Low pH pre-treatment & Group 2 Low pH 2 months after treatment \\
\hline Mean & 7.5750 & 7.0000 \\
\hline Stdev & 0.1893 & 0.1414 \\
\hline Standard error & 0.0947 & 0.0707 \\
\hline Paired difference t-test & $t=1.960 \mathrm{df}=3$ & \\
\hline$P$ value & 0.0040 & \\
\hline Significantly different $(P<0.05)$ & Yes & \\
\hline pH comparison & Group 1 High pH pre-treatment & Group 2 High pH 2 months after treatment \\
\hline Mean & 8.2250 & 8.0500 \\
\hline Stdev & 0.0960 & 0.3510 \\
\hline Standard error & 0.0480 & 0.1760 \\
\hline Paired difference t-test & $t=0.9272 \mathrm{df}=3$ & \\
\hline$P$ value & 0.3988 & \\
\hline Significantly different $(P<0.05)$ & No & \\
\hline OM comparison & Group 1 Low pH pre-treatment & Group 2 Low pH 2 months after treatment \\
\hline Mean & 0.7250 & 1.0500 \\
\hline Stdev & 0.0500 & 0.0577 \\
\hline Standard error & 0.0250 & 0.0289 \\
\hline Paired difference t-test & $t=13.00 \mathrm{df}=3$ & \\
\hline$P$ value & 0.0002 & \\
\hline Significantly different $(P<0.05)$ & Yes & \\
\hline OM comparison & Group 1 High pH pre-treatment & Group 2 High pH 2 months after treatment \\
\hline Mean & 1.1250 & 0.8000 \\
\hline Stdev & 0.1258 & 0.0817 \\
\hline Standard error & 0.0629 & 0.0408 \\
\hline Paired difference t-test & $\mathrm{t}=6.789 \mathrm{df}=3$ & \\
\hline$P$ value & 0.0070 & \\
\hline Significantly different $(P<0.05)$ & Yes & \\
\hline CEC comparison & Group 1 Low pH pre-treatment & Group 2 Low pH 2 months after treatment \\
\hline Mean & 10.6750 & 8.3250 \\
\hline Stdev & 1.1587 & 0.3202 \\
\hline Standard error & 0.5793 & 0.1601 \\
\hline Paired difference t-test & $\mathrm{t}=4.421 \mathrm{df}=3$ & \\
\hline$P$ value & 0.0229 & \\
\hline Significantly different $(P<0.05)$ & Yes & \\
\hline CEC comparison & Group 1 High pH pre-treatment & Group 2 High pH 2 months after treatment \\
\hline Mean & 17.3750 & 11.0750 \\
\hline Stdev & 1.1300 & 2.7910 \\
\hline Standard error & 0.5650 & 1.3950 \\
\hline Paired difference t-test & $t=4.181 \mathrm{df}=3$ & \\
\hline$P$ value & 0.0249 & \\
\hline Significantly different $(P<0.05)$ & Yes & \\
\hline
\end{tabular}




\section{Dataset 1. Microalgae counts raw data}

http://dx.doi.org/10.5256/f1000research.4016.d36846

Figure 3 data (sheet 1): Total counts for microalgae (blue, green and diatoms) included in Figure 3 in the manuscript for plots before and after harvest.

Figure 3 data (sheet 2): Individual counts for microalgae.

Our results indicate that prior to GOgreen ${ }^{\circledR}$ treatment, the total microalgae population in the soil of the test plots was composed of $60 \%$ blue-green algae, $25 \%$ green algae and $15 \%$ diatoms (Figure $3 \mathrm{~A}$ ). The ratio of green to blue-algae was 0.42 . In the control plot, the ratio of green to blue-green algae pre-treatment was approximately 0.45 (Figure $3 \mathrm{~B}$ ) indicating uniformity in the distribution of microalgae by plots before treatment.

In soils with $\mathrm{pH}<8.0$, green algae were more abundant, which also correlated with the control at this $\mathrm{pH}$ (Figures $3 \mathrm{C}$ and D). The amount of diatoms was higher in the treated plots than in the controls. In soils with $\mathrm{pH}>8.0$, green algae counts were lower than those of blue algae (Figures $3 \mathrm{E}$ and F).

The results obtained two months after harvest indicate the percentages of blue-green algae and green algae were similar after
GOgreen ${ }^{\circledR}$ treatment (Figure 3G). In contrast, the controls plots showed a 50\% reduction in the blue-green algae counts when compared to the number of green algae (Figure 3H). Although diatoms also appeared in the controls two months after harvest, their counts were significantly higher in the treated plots as shown in Figure $3 \mathrm{G}$.

The comparison between the $\mathrm{pH}<8.0$ and the $\mathrm{pH}>8.0$ controls indicates that there were small differences between their values (1.53 vs. 1.11 respectively). However, the difference between green and blue-green algae in the treated plots was significant (4.69 vs 1.87) indicating differences in microalgae diversity based on $\mathrm{pH}$. In both cases, the ratio in terms of percentages was higher than the ratio of the controls, indicating that treatment does have an impact on microalgae populations. Over time, all treated plots showed higher counts of green algae than blue-algae. When compared to untreated plots, those numbers showed a significant increase as the controls pre-treatment indicated higher numbers of blue-green algae in the soil. Furthermore, diatom concentrations increased in all treated plots. The diatom counts were much higher in soil with $\mathrm{pH}>8.0$.

\section{Differences in soil pH before and after treatment}

The results of this study indicate differences between soil $\mathrm{pH}$ in the plots with $\mathrm{pH}<8.0$ treated with GOgreen ${ }^{\circledR}$ two months after harvest (Figure 4A). Although the control plot did not show a

\section{A. Differences in $\mathrm{pH}$ after GOgreen ${ }^{\circledR}$ applicant in soil}

B.

\section{Differences in pH after GOgreen ${ }^{\circledR}$ applicant in soil} at $\mathrm{pH}>\mathbf{8 . 0}$

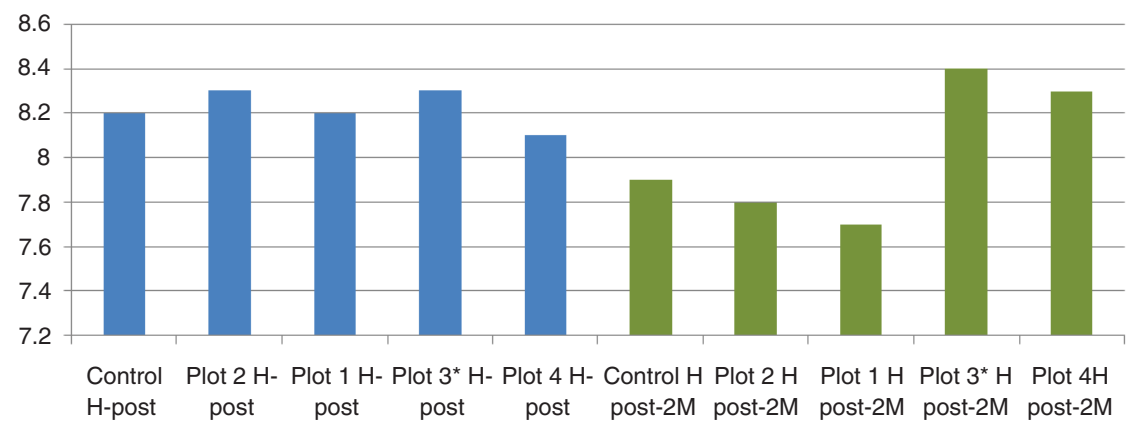

Figure 4. Differences in soil pH before and after GOgreen ${ }^{\circledR}$ application. A. Comparison of $\mathrm{pH}$ values observed at harvest and two months post-harvest in soils with $\mathrm{pH}<8.0$. Blue: $\mathrm{pH}$ values for plots at harvest. Red: $\mathrm{pH}$ values for plots 2 months after harvest. $\mathbf{B}$. Comparison of $\mathrm{pH}$ values observed at harvest and two months post-harvest in soils with $\mathrm{pH}<8.0$. Blue: $\mathrm{pH}$ values at harvest. Green: values 2 months after harvest. 
substantial change in $\mathrm{pH}$ (initial $\mathrm{pH}$ was 6.9 and $\mathrm{pH}$ after harvest was 7.0), the treated plots did show substantial changes over time. A trend based on rates of application was not obvious.

It is clear from Figure 4A that in plots with soil $\mathrm{pH}>7.0$ at the end of harvest, the $\mathrm{pH}$ of the soil reached values closer to neutral two months later. In soils with $\mathrm{pH}>8.0$ the trend was not as noticeable. However, $\mathrm{pH}$ decreased to values closer to 7.0 in plots 1 and 2, as well as the controls.

An observation worth noting is the difference in $\mathrm{pH}$ in plots 3 and plots 4 at $\mathrm{pH}>8.0$ when compared to the other plots as seen in Figure 4B. At this $\mathrm{pH}$, treatment with $\mathrm{GOgreen}^{\circledR}$ the previous year (plot 3) and with twice the recommended application rate (plot 4) resulted in a $\mathrm{pH}$ increase of 0.2 units two months after harvest when compared to the other plots. This result contradicts the observations in which $\mathrm{pH}$ decreased in the soil two months after harvest in plots 1 and 2.

\section{Discussion}

A conventional approach was implemented to evaluate microalgae diversity in soil samples collected at a depth of 6 inches after herbicide and fertilizer treatment. Soil was treated with GOgreen ${ }^{\circledR}$ in an effort to restore and improve microalgae diversity and soil properties. This method included isolation, culture and species identification based on morphological criteria. This method has been successfully used by other investigators (Kostikov et al., 2001).

The results presented in this manuscript demonstrate that treatment with GOgreen ${ }^{\circledR}$ has significant and measurable effects on soil OM content, $\mathrm{CEC}, \mathrm{pH}$ and microalgae species diversity suggesting positive effects of this formulation on soil conditions, making them more suitable to sustain crops. Although studies in soil are affected by a variety of biotic and abiotic factors, the effects of GOgreen ${ }^{\circledR}$ are evident in terms of increases in microalgae species diversity. Abiotic factors considered in this study included light intensity, temperature and humidity. Control of external biotic and abiotic factors in the soil is extremely difficult and therefore the best approximation that could be done in a study of this nature is to compare soils that have been treated under the same conditions with simultaneous sampling.

Temperature changes in the environment during the time of the study were considered since it has been reported that blue-green algae are photo inhibited by high light intensities at low temperatures. Temperature can be considered as the most important limiting factor in outdoor cultivation during the winter (Malakar \& Kalita, 2012). Blue-green algae growth is enhanced by increasing light density up to the point of light saturation, at which point photosynthetic activity reaches its maximum (Abu et al., 2007; Pandey \& Tiwari, 2010). At high light densities, photosynthetic capacity decreases and blue-green algae growth is inhibited. As soil samples were taken from all plots during the cold months of November and February, it is possible to hypothesize that the low counts of blue-green algae found in the treatment plots and the controls after GOgreen ${ }^{\circledR}$ treatment are directly related to changes in ambient temperature and light intensity between soil sampling times. This could be a possible explanation for the differences encountered in the parameters measured between pre and post GOgreen ${ }^{\circledR}$ applications. However, as all plots (treated and not treated) were exposed to the same environmental conditions, it is highly unlikely that the differences found in the treated plots versus the control plot were due to cold temperatures or intense light. The difference must be related to different soil characteristics as a result of the treatment.

Despite abundant studies on soil algae (Johansen, 1993; Metting, 1981; Lukešová, 1993; Lukešová, 2001; Lukešová \& Hoffmann, 1996; Neustupa, 2001; Starks et al., 1981; Sukala \& Davis, 1994; Tsujimura et al., 2000), it is still difficult to correlate species diversity and their influence on ecosystem functions. Therefore, this manuscript does not attempt to correlate species diversity with metabolic, ion or gas exchanges. Instead, the focus lies on algae species diversity after use of an organic formulation such as GOgreen ${ }^{\circledR}$ and to correlate these findings with indicators of soil quality such as $\mathrm{OM}$ and CEC.

The primary objective of these studies was to determine the effects of GOgreen ${ }^{\circledR}$ on algae species diversity after herbicide application. The results of this study support the findings that Zancan and Zuzyamkhmetov encountered in corn fields subjected to lengthy periods of intense fertilization. Their results indicate a reduction in species diversity and a suppression of blue-green algae development in fields treated with fertilizers and herbicides (Kuzyakhmetov, 1998; Zancan et al., 2006). The control shown in Figure 3B, indicates low species diversity (diatoms are absent) encountered in the soil prior to GOgreen ${ }^{\circledR}$ treatment but after fertilizer and herbicide treatment. The data shown in this manuscript confirms the profound effect of agricultural practices including herbicide and pesticide application on the structure of soil algal communities.

Herbicides have also previously been correlated to changes in microalgae populations in aquatic ecosystems (Bérard \& Benninghoff, 2001; Bérard et al., 1999) and decreased density of algal assemblages in plots. Lenacil and Pyrazon for example, have been shown to diminish species diversity and decrease microalgae counts in soil (Zurek, 1981). Herbicides and pesticides influence the range of genera and the number of algal cells, blue-green in particular, present at any given time in vitro and in vivo (McCann \& Cullimore,1979; Megharaj et al., 1999; Metting \& Rayburn, 1979; Mostafa \& Helling, 2002).

One of the main groups considered the diatoms a valuable tool to assess biological conditions in wetlands (Doherty et al. 2000; Stevenson, 2001). The response of diatoms to changes in surrounding land and water column characteristics has been documented previously and many diatom taxa have been identified from a range of sites throughout the world (Stevenson, 2001). Diatoms appear to have a consistent tolerance of a wide range of environmental parameters, such as light, moisture, $\mathrm{pH}$, salinity, oxygen and inorganic and organic nutrients (van Dam et al., 1994). Responses to $\mathrm{pH}$ (Pan \& Stevenson, 1996) and heavy metal loading (Charles et al., 1996) have also been used to predict environmental pollution. The US Environmental Protection Agency (USEPA) (2002) reported that diatoms are one of the most commonly used microorganisms in observations from aquatic ecosystems for assessing biological, physical, and chemical conditions. Through this study, it can be 
concluded that GOgreen ${ }^{\circledR}$ increased diatom numbers and species diversity in the treated plots compared to the controls indicating that GOgreen ${ }^{\circledR}$ has a restorative effect on soil quality after herbicide treatment in heavily farmed soil. Additionally, these results indicate that the observations from aquatic ecosystems can be extrapolated to terrestrial environments.

In terms of specific differences in species diversity related to green and blue-green algae, a $17 \%$ increase was observed in the total counts of green microalgae in the GOgreen ${ }^{\circledR}$ treated plots at $\mathrm{pH}$ $<8.0$ when compared to the control, while a $22 \%$ decrease was observed in blue-green algae in the same plots. Contrary to these results, a $22 \%$ decrease in green microalgae was observed in the GOgreen ${ }^{\circledR}$ treated plots at $\mathrm{pH}>8.0$ when compared to the controls, while a $30 \%$ decrease was observed in blue-green algae counts when compared to the control at this high $\mathrm{pH}$ value. These results indicate that the effects of GOgreen ${ }^{\circledR}$ application are different and highly dependent on soil $\mathrm{pH}$.

The $\mathrm{pH}$ of all plots tested varied between 6.9 to 8.4 , therefore many of the microalgal classes were represented. Blue-green algae are unable to survive in acidic conditions (Brock, 1973), but green algae are able to survive in soils with $\mathrm{pH}<7.0$ (Lukešová \& Hoffmann, 1995). Neutral conditions support the growth of algal communities representing all major taxonomic groups (Lukešová, 2001; Metting, 1981). The percentage of blue-green algae observed in the control plot at $\mathrm{pH}<8.0$ was $38 \%$ (Figure 3D) versus $45 \%$ in the control plot at $\mathrm{pH}>8.0$ (Figure 3F), which supports the findings by the above mentioned investigators. In contrast, the values for green algae in the two controls were similar (58\% and 50\%). These results indicate increased microalgal species diversity in the GOgreen ${ }^{\circledR}$ treated plots versus the controls within the $\mathrm{pH}$ range tested.

An increase in diatom numbers and diversity was observed at all $\mathrm{pH}$ values when treatment plots were compared to controls not treated with GOgreen ${ }^{\circledR}$. The results of treatment with GOgreen ${ }^{\circledR}$ were different between soil with $\mathrm{pH}<8.0$ and soil with $\mathrm{pH}>8.0$. At all $\mathrm{pH}$ values, an increase in diatom concentration was observed in the GOgreen ${ }^{\circledR}$ treated plots when compared to the controls, but this effect was higher in soils with $\mathrm{pH}>8.0$, resulting in a $57 \%$ of total diversity composed of diatoms (Figure $3 \mathrm{E}$ ) versus $9 \%$ of diatoms at $\mathrm{pH}<8.0$ (Figure 3C). The main species found in the study were: Pennate diatom, Caposira, Raphid diatom, Geminella, Navicula diatom, Centric diatom, Tessillaria, Pinnularia.

The second objective of these studies was to determine the effect of GOgreen ${ }^{\circledR}$ on OM and CEC. Both OM and CEC depend on soil pH. Optimum $\mathrm{pH}$ for corn ranges between 5.5-7.0 (Havlin et al., 1999). Our results suggest that soils starting at $\mathrm{pH}<8.0$ are most likely to fall within the optimal $\mathrm{pH}$ range for corn after GOgreen ${ }^{\circledR}$ treatment.

Soil OM serves multiple functions including nutrient storage and soil aggregation. Soils with high CECs are able to bind more monovalent and divalent cations through available sites in clay and OM particles. A soil with a high CEC also has an increased buffering capacity indicating that this soil is able to resist fluctuations in $\mathrm{pH}$.
Soils with a high clay content and/or OM will typically have higher CEC and buffering capacity than silty or sandy soils, as organic materials provide additional binding sites for cations (CUCE, 2007). In this study, high OM correlated with high CEC values of the plots before GOgreen ${ }^{\circledR}$ application. At harvest, CEC was higher in soil with $\mathrm{pH}>8.0$, which is consistent with the presence of negative charges in the absence of acidic values that in turn have the ability to bind cations. Two months after harvest, values for CEC were lower at both $\mathrm{pH}$ ranges as it is expected after harvest due to soil depletion. These changes also correlated with $\mathrm{pH}$ values two months after harvest as the $\mathrm{pH}$ lowered for both types of soil. The most interesting observation was the fact that the CEC was around 8.0 at both $\mathrm{pH}$ values two months after harvest indicating a stabilization of CEC in the soil regardless of $\mathrm{pH}$. Although this value is lower than those encountered at harvest, a low CEC value indicates that fewer cations such as $\mathrm{K}^{+}, \mathrm{Ca}^{2+}, \mathrm{Mg}^{2+}$, to name a few, will be bound to soil particles and more available for nutrient uptake by the plant. Nitrogen will also be more available and less lime will be necessary to correct $\mathrm{pH}$ fluctuations. In soils with $\mathrm{pH}$ around 8.0 such as those found in the Western U.S., large amounts of naturallyoccurring lime are typically responsible for the increased $\mathrm{pH}$. This "free lime" buffers $\mathrm{pH}$ in the alkaline range making it very difficult to change soil $\mathrm{pH}$. Calcium carbonate $\left(\mathrm{CaCO}_{3}\right)$ is commonly found in these soils. For these particular soils, larger quantities of amendments are needed to lower the $\mathrm{pH}$ converting $\mathrm{pH}$ modification in alternatives that are not cost effective. Addition of organic matter is typically used to lower $\mathrm{pH}$ but not all sources of organic matter are effective or safe for human consumption. GOgreen ${ }^{\circledR}$ lowers the $\mathrm{pH}$ in soils with a $\mathrm{pH}$ higher than 7.0 emerging as an economical alternative that is safe for humans and the environment.

In soil, the presence of living organisms has proven critical to OM formation. Soils with $\mathrm{OM}$ values around $1.0 \%$ are typically found in the desert (CUCE, 2007). Soil OM - the product of on-site biological decomposition - affects the chemical and physical properties of the soil and its overall health. Its composition and breakdown rate affect the soil structure and porosity, the water infiltration rate and moisture holding capacity of soils, the diversity and biological activity of soil organisms, and plant nutrient availability (Bot \& Benites, 2005). Where the rate of OM addition is less than the rate of its decomposition, soil OM declines. Conversely, where the rate of addition is higher than the rate of decomposition, soil $\mathrm{OM}$ increases. The observations presented in this study regarding the differences in $\mathrm{OM}$ at the $\mathrm{pH}$ values tested indicate that the rate of OM addition after GOgreen ${ }^{\circledR}$ application is higher than the rate of decomposition in soils with $\mathrm{pH}<8.0$. The opposite is true for soils with $\mathrm{pH}>8.0$. However, further studies are needed to test this hypothesis. As changes in OM are lower than 1-2\% per year of the total OM in the soil, the effects of GOgreen ${ }^{\circledR}$ algae application will only become significant after several years. For this purpose, this study has been extended in order to monitor the plots described during subsequent years of continuous harvest usage.

As land available for cultivation becomes scarce due to increasing populations, the need for improved soil quality is now recognized at a global scale (Elliott et al., 1996). Soil communities co-exist in constant interactions with each other (Gerson, 1974; Thirup et al., 2000; Yeates et al., 1993). These interactions are crucial to regulate 
soil activity and may be disturbed by soil pollution, herbicides, pesticides, fertilizers and management practices (Pankhurst, 1997; Paoletti et al., 1988).

Methods to determine soil quality are varied but scholars have identified microorganisms as potential bio indicators of soil quality (Pipe \& Cullimore, 1980; Roper \& Opel-Keller, 1997). It has been proposed that approaches to study ecological and eco-toxicological impacts of management and agricultural practices on soil quality should be monitored with the use of multimicrobial bio indicators (Bérard et al., 2005). Soil microalgae depend on soil physical and chemical characteristics and therefore, these organisms have been used for decades as bio indicators to estimate the eco-toxicological impact of agricultural management practices and herbicide application (Fujita \& Nakahara, 1999; McCann \& Cullimore, 1979; Pipe, 1992). Biodiversity is therefore an indicator of soil quality and a crucial component to evaluate the success of a particular remediation strategy. The use of biodiversity as an indicator is limited by the incomplete knowledge regarding microorganisms present in a particular ecosystem (Paoletti, 1999).

Microalgae, and diatoms in particular, respond to different ecological gradients and are therefore useful tools for bio monitoring studies in aquatic and terrestrial ecosystems. It has been demonstrated that diatom diversity tends to be higher in biodynamic systems than in conventional systems. Redundancy analysis (RDA) has suggested that diatom community structure differs significantly between organic and conventional systems (Heger et al., 2012).

Microalgae concentrate in the top few inches of the soil because they need moisture and light to perform photosynthesis. They are located in the first biological layer directly affected by environmental changes, both natural and manmade. Consequently, microalgae composition varies in the soil over several weeks depending on treatment and their numbers are highly influenced by environmental and seasonal factors specific to each region (Hoffmann, 1989; Metting, 1981; Whitton, 2000). These results corroborate previous findings and highlight the importance of $\mathrm{CEC}, \mathrm{OM}$ and $\mathrm{pH}$ variations in increased microalgae species diversity through GOgreen ${ }^{\circledR}$ application.

\section{Data availability}

F1000Research: Dataset 1. Microalgae counts raw data, 10.5256/ f1000research.4016.d36846 (Hastings, 2014).

\section{Author contributions}

$\mathrm{KH}, \mathrm{ML}, \mathrm{LB}$ and GD conceived the study. KH and LS designed the experiments. KH, LS, GD, JD, and DZ carried out the research. $\mathrm{LB}$ and ML contributed to the design of experiments and provided expertise in rates of application, costs and budgets. MCM prepared the first draft of the manuscript. KH, JD, DZ, ML, MCM and GD contributed to the experimental design and preparation of the manuscript. All authors were involved in the revision of the draft manuscript and have agreed to the final content.

\section{Competing interests}

No competing interests were disclosed.

\section{Grant information}

This study was funded by Global Organics, LLC. Goodyear, AZ, USA.

\section{Acknowledgements}

The authors would like to thank Irrigation Research Facility (IRF) Yuma, CO and Midwest Labs Omaha, NE for their help with plot and crop treatments and collection.
Abu GO, Ogbonda KH, Aminigo E: Optimization studies of biomass production and protein biosynthesis in a Spirulina sp. isolated from an oil-polluted flamepit in the Niger Delta. Afr J Biotechnol. 2007; 6: 2550-4.

Reference Source

Alexander M: Introduction to Soil Microbiology. Wiley, NY. 1977; 467. Reference Source

Beakes G, Canter HM, Jaworski GHM: Zoospores. ultrastructure of Zygorhizidium affluens Canter and Z. planktonicum Canter, two chytrids parasitizing the diatom Asterionella formosa Hassall. Can J Bot 1988; 66: 1054-1067. Publisher Full Text

Bérard A, Benninghoff C: Pollution-induced community tolerance (PICT) and seasonal variations in the sensitivity of phytoplankton to atrazine in nanocosms. Chemosphere. 2001; 45(4-5): 427-437.

PubMed Abstract | Publisher Full Text

Bérard A, Dorigo U, Humbert JF, et al.: Microalgae community structure analysis based on 18S rDNA amplification from DNA extracted directly from soil as a potential soil bioindicator. Agronomie. 2005; 25: 1-7.

Publisher Full Text

Bérard A, Leboulanger C, Pelte T: Tolerance of Oscillatoria limnetica

Lemmermann to atrazine in natural phytoplankton populations and in pure culture: Influence of Season and Temperature. Arch Environ Contam Toxicol. 1999; 37(4): 472-479.

PubMed Abstract | Publisher Full Text

Bold HC: The morphology of Chlamydomonas chlamydogama sp. nov. Bull Torrey Bot Club. 1949; 76(2): 101-8.

Publisher Full Text

Bot A, Benites J: The importance of soil organic matter, key to droughtresistant soil and sustained food production. FAO Soils Bulletin 80 . Rome (Italy): FAO. 2005.

Reference Source
Brock TD: Primary colonization of Surtscy, with special reference to the blue-green algae. Oikos. 1973; 24: 239-243.

Publisher Full Text

Charles $D$, Aker F, Roberts NA: Diatom periphyton in Montana lakes and wetlands: ecology and potential as bioassessment indicators. Patrick Center of Environmental Research, Environmental Research Division. The Academy of Natural Sciences, Philadelphia, Pennsylvania, USA. 1996.

Cornell University Cooperative Extension (CUCE). Cation exchange capacity (CEC). Agronomy Fact Sheet Series \# 22. Department of Crop and Soil Sciences, College of Agriculture and Life Sciences, Cornell University. 2007. Reference Source

Doherty SM, Cohen M, Lane C, et al: Biological criteria for inland freshwater wetlands in Florida: a review of technical and scientific literature (1990-1999). Report to the United States Environmental Protection Agency, Center for Wetlands, University of Florida, Gainesville, Florida, USA. 2000.

Reference Source

Doran JW, Parkin TB: Defining and assessing soil quality. In: J.W. Doran, D.C. Coleman, D.F. Bezdicek, and B.A. Stewart (eds.), Defining Soil Quality for a Sustainable Environment. SSSA Spec. Pub. No. 35. Soil Sci Soc Am Am Soc. Argon., Madison, WI. 1994; 3-21.

Publisher Full Text

Elliott ET, Paustian K, Frey SD: Modeling the measurable or measuring the modelable: a hierarchical approach to isolating meaningful soil organic matter fractionations. In: Powlson, D.S., Smith, P., Smith, J.U. (Eds.), Evaluation of Soil Organic Matter Models. Springer-Verlag, NATO ASI Series. 1996; 161-179. Publisher Full Text

Fujita $\mathrm{Y}$, Nakahara $\mathrm{H}$ : Effects of cultivation conditions on algal communities in paddy soils. Jap J Limnol. 1999; 60(1): 77-86.

Gaydon DS, Probert ME, Buresh RJ, et al.: Modelling the role of algae in rice crop nutrition and soil organic carbon maintenance. European Journal of 
Agronomy. 2012; 39: 35-43.

Publisher Full Text

Gerson U: The associations of algae with arthropods. Rev Algol. 1974; 11: 18-41. Reference Source

Goyal SK: Algae and the soil environment. Phykos. 1997; 36: 1-13.

Hargrove WW, Luxmore RJ: A New High-Resolution National Map of Vegetation Ecoregions Produced Empirically Using Multivariate Spatial Clustering. 1988. Reference Source

Hastings KL, Smith LE, Lindsay M, et al:: Microalgae counts raw data.

F1000Research. 2014.

Data Source

Havlin JL, Beaton JD, Tisdale SL, et al:: Soil Fertility and Fertilizers. 6th Edition. Prentice Hall. Upper Saddle River, NJ. 1999; 499.

Reference Source

Heger TJ, Straub F, Mitchell EAD: Impact of farming practices on soil diatoms and testate amoebae: A pilot study in the DOK-trial at Therwil, Switzerland. European Journal of Soil Biology. 2012; 49: 31-36.

Publisher Full Text

Hoffmann L: Algae of terrestrial habitats. Bot Rev. 1989; 55(2): 77-105.

Publisher Full Text

Johansen JR: Cryptogamic crusts of semiarid and arid lands of North America.

J Phycol. 1993; 29(2): 140-147.

Publisher Full Text

Kennedy AC, Papendick RI: Microbial characteristics of soil quality. Journal of Soil and Water Conservation. 1995; 50: 243-248.

Reference Source

Kostikov IJ, Romanenko PO, Demchenko EM, et al:: Soil algae of Ukraine (Vodorosti gruntiv Ukrajiny). Phytosotsiologichniy center, Kiev. 2001; 300.

Kuzyakhmetov GG: Algological evaluation of the toxicity of copper compounds in grey forest soil and leached chernozem. Eurasian Soil Sci. 1998; 31(8): 877-882. Reference Source

Lukešová A: Soil algae in four secondary successional stages on abandoned fields. Algological Stud. 1993; 71: 81-102.

Reference Source

Lukešová, A: Soil algae in brown coal and lignite post-mining areas in Central Europe (Czech Republic and Germany). Restoration Ecol. 2001; 9(4): 341-350. Publisher Full Text

Lukešová A, Hoffmann L: Soil algae from acid rain impacted forest areas of the Krušné hory Mountains. Effect of pH on growth. Algological Stud. 1995; 78(2): 39-51.

Lukešová A, Hoffmann L: Soil algae from acid rain impacted forest areas of the Krušné hory Mountains. Algal communities Vegetation. 1996; 125: 123-136. Publisher Full Text

Malakar E, Kalita MC: A perspective towards development and commercialization of potential bga biofertilizers of Assam, North East India and carrier materials for BGA mass production and Inoculum development. Annals of Biological Research. 2012; 3(1): 814-828.

Reference Source

Martin E, Hine R: "Succession". A Dictionary of Biology (6th ed.). Oxford University Press. 2008.

Reference Source

McCann AE, Cullimore DR: Influence of pesticides on the soil algal flora.

Residue Rev. 1979; 72: 1-31.

Publisher Full Text

Megharaj M, Singleton I, Kookana R, et al.: Persistence and effects of fenamiphos on native algal populations and enzymatic activities in soil. Soil Biol Biochem. 1999; 31(11): 1549-1553.

Publisher Full Text

Metting B: The systematics and ecology of soil algae. Bot Rev. 1981; 47(2): 195-312. Publisher Full Text

Metting B, Rayburn W: Algal communities and soil microenvironments in an Eastern Washington silt loam. Soil Sci. 1979; 127(2): 74-78.

Publisher Full Text

Mostafa FI, Helling CS: Impact of four pesticides on the growth and metabolic activities of two photosynthetic algae. J Environ Sci Health B. 2002; 37(5): 417-444.

PubMed Abstract | Publisher Full Text

Neustupa J: Soil algae from marlstone-substratum based biotopes in the Nature park Džbán (Central Bohemia, Czech Republic) with special attention to the natural treeless localities. Algological Stud. 2001; 101: 109-120. Reference Source

Pan Y, Stevenson RJ: Gradient analysis of diatom assemblages in western Kentucky wetlands. Journal of Phycology. 1996; 32(2): 222-232.

Publisher Full Text

Pandey JP, Tiwari A: Optimization of biomass production of Spirulina maxima. $J$ Algal Biomass Utilization. 2010; 1: 20-32.

Reference Source

Pankhurst C, Doube BM, Gupta V: Biological Indicators of Soil Health. CAB International, London, 1997.

Reference Source

Paoletti MG: Soil invertebrates in cultivated and uncultivated soils in North-East
Italy. Redia. 1988; 71(2): 501-563

Reference Source

Paoletti MG: Some unorthodox thoughts: what Western agriculture should learn from Chinese agriculture. Critical review in Plant Sciences. 1999; 18(3): 475-487. Publisher Full Text

Paul EA, Clark FE: Soil Microbiology and Biochemistry. Academic Press, Inc. San Diego. 1989; 273

Reference Source

Pipe AE: Pesticide effects on soil algae and cyanobacteria. Bull Environ Contam Toxicol. 1992; 127: 95-170.

Publisher Full Text

Pipe AE, Cullimore DR: An implanted slide technique for examining the effects of the herbicide Diuron on soil algae. Bull Environ Contam Toxicol. 1980; 24(1): 306-312.

PubMed Abstract | Publisher Full Text

Pringsheim EG: Pure cultures of Algae: their preparation \& maintenance. CUP Archive. 1946

Reference Source

Roper MM, Gupta V: Management practices and soil biota. Aus J Soil Res. 1995; 33(3): 321-339.

Publisher Full Text

Roper MM, Ophel-Keller KM: Soil microflora as bioindicators of soil health. in: Pankhurst C.E., Doube B.M., Gupta V.V.S.R. (Eds.). Biological indicators of soil health. 1997; 157-177.

Reference Source

Ruble RW, Davis JS: Soil algae from fallow potato fields in south Florida (USA) marl. Nova Hedwigia. 1988; 47(3-4): 403-414.

Reference Source

Sims GK: Biological degradation of soil. Advances in Soil Sci. 1990; 11: 289-329. Publisher Full Text

Sparling GP: Soil microbial biomass, activity and nutrient cycling as indicators of soil health. Biological Indicators of Soil Health, ed. C.E. Pankurst, B.N. Doube, \& V.S.R. Gupta, CAB: Wallingford. 1997; 4. : 97-119.

Reference Source

Stanier RY, Kunisawa R, Mandel M, et al:: Purification and properties of unicellula blue-green algae (Order Chroococcales). Bacteriol Rev. 1971; 35(2): 171-305. PubMed Abstract | Free Full Text

Starks TL, Shubert LE, Trainor FR: Ecology of soil algae: a review. Phycologia.

1981; 20(1): 65-80.

Publisher Full Text

Stevenson RJ: Using algae to assess wetlands with multivariate statistics, multimetric indices, and an ecological risk assessment framework. in D.P.

Batzer, R.B. Rader, and S.A. Wissinger, editors. Bioassessment and management of North American freshwater wetlands. John Wiley and Sons, New York, USA 2001 ; $113-140$.

Reference Source

Sukala BL, Davis JS: Algae from nonfertilized soils and soils treated with fertilizers and lime of North Central Florida. Nova Hedwigia. 1994; 59: 33-46. Reference Source

Thirup L, Ekelund F, Johnsen K, et al.: Population dynamics of the fast-growing sub-populations of Pseudmonas and total bacteria, and their protozoan grazers, revealed by fenpropimorph treatment. Soil Biol Biochem. 2000; 32(11-12): 1615-1623.

Publisher Full Text

Tsujimura S, Nakahara H, Ishida N: Estimation of soil algal biomass in salinized irrigation land: a comparison of culture dilution and chlorophyll a extraction methods. J Appl Phycol. 2000; 12(1): 1-8.

Publisher Full Text

van Dam H, Mertens A, Sinkeldam J: A coded checklist and ecological indicator values of freshwater diatoms from the Netherlands. Netherlands Journal of Aquatic Ecology. 1994; 28(1): 117-133.

Publisher Full Text

Warkentin B: The changing concept of soil quality. J Soil Water Conserv. 1995; 50(3): 226-228.

Reference Source

Whitton BA: Soils and rice-field. in: Whitton B.A., Potts M. (Eds.). The Ecology of Cyanobacteria, their diversity in time and space. 2000; 233-255.

Publisher Full Text

Yeates GW, Bongers T, de Goede RG, et al:: Feeding habits in soil nematodes families and genera-an outline for soil ecologists. J Nematol. 1993; 25(3): 315-331.

PubMed Abstract | Free Full Text

Zancan S, Trevisan R, Paoletti MG: Soil algae composition under different agroecosystems in North-Eastern Italy. Agriculture, Ecosystems and Environment 2006; 112(1): 1-12.

Publisher Full Text

Zenova GM, Shtina EA, Dedysh SN, et al.: Ecological relations of algae in biocenoses. Mikrobiologiya. 1995; 64(2): 121-133.

Reference Source

Zurek L: The Influence of the Herbicides Lenacil and Pyrazon on the Soi Algae. Ekologia polska-Polish Pol J Ecol. 1981; 29(3): 327-342.

Reference Source 


\section{Open Peer Review}

\section{Current Peer Review Status:}

\section{Version 1}

Reviewer Report 22 June 2015

https://doi.org/10.5256/f1000research.4303.r9124

(C) 2015 Brown J. This is an open access peer review report distributed under the terms of the Creative Commons Attribution License, which permits unrestricted use, distribution, and reproduction in any medium, provided the original work is properly cited.

\section{Judith K. Brown}

School of Plant Sciences, The University of Arizona, Tucson, AZ, USA

The title seems appropriate for the article content and the abstract provides a summary of the research aim, results, and major conclusion.

The objective of the study was to determine the effect of GOgreen ${ }^{\circledR}$ on algae species diversity in a field heavily cultivated (farmed) and subjected to herbicide application, which is reported to diminish microalgal species diversity ('assemblages'). Use of the product is purported to increase the content of green to blue-green algae, thereby increasing soil health with respect to $\mathrm{pH}$ and other parameters. The hypothesis is that the proprietary algal community preparations applied to the soil prior to cultivation of a corn crop would provide beneficial effects measureable in terms of $\mathrm{pH}$, cation exchange capacity, organic matter content, and algal content (green, blue-green, diatoms). The second objective addressed the effect of the treatment on OM and CEC, which are $\mathrm{pH}$ dependent.

The methodologies and analyses are well described and are appropriate for the research questions addressed pertaining to a proprietary microalgal product (GOgreen) applied through an irrigation system to corn plants (half acre plots) grown in soil previously treated with an herbicides and subjected to routine use for farming (consecutive planting/harvesting seasons). The premise is that the naturally occurring soil microalgal species, which contribute to soil health, are hindered by herbicide treatment. The algal species in treated soil sampled at a 6 -inch depth were identified morphologically prior to the treatment, and at 4,6,7, and 8 weeks after seedling emergence, at V5 stage of plant growth, and at harvest. The experimental control consisted of adjacent plot of land that was not treated with the product.

The conclusions appear to be justified based on the aim, methods, and results reported.

The results suggested that treating soil with the product showed improvement in terms of organic matter content (increased when initial pH was greater than $\mathrm{pH} 8.0$ but lower in soil of starting pH less than 8.0), cation exchange capacity, and increased diversity of certain (green and blue-green) microalgal species in soil samples monitored throughout the study. 
Some positive effects of the treatment were observed with respect to soil $\mathrm{pH}$ that is attributed to altered microalgal composition, and subsequently, with respect to CEC and OM. Initial $\mathrm{pH}$ readings in the plot were 8.3 and 6.8 in different parts of the field, respectively. They conclude that treatment with GOgreen ${ }^{\circledR}$ resulted in improved OM content in the soil during the cropping season, but not longer than two months after harvest. Also, they conclude that increased OM was associated with differences in initial $\mathrm{pH}$. The results are reasonably conclusive in favor of a transient modification in soil parameters due to the treatment with the proprietary microalgal preparations. The conclusions seem to indicate that the product must be applied at each planting. This is no different from the routine application of fertilizers and other conditioning agents used to improve soil structure and fertility, and so the product does appear to make a positive contribution to the soil for crop production (in this case, for maize).

NOTE: the authors should double check the $\mathrm{pH}$ values - in Methods the low pH is reported at 6.8, but in the results they mention $\mathrm{pH} 6.9$ instead.

The data inform the aims/methods; the methods are appropriately detailed such that the experiments could be reproduced in another laboratory. No discrepancies or format issues are apparent.

The manuscript appears suitable for indexation based on my understanding of the topic, and review of the methods, results, and conclusions.

Competing Interests: No competing interests were disclosed.

I confirm that I have read this submission and believe that I have an appropriate level of expertise to confirm that it is of an acceptable scientific standard.

Reviewer Report 24 November 2014

https://doi.org/10.5256/f1000research.4303.r6723

(C) 2014 Bowker $\mathbf{M}$. This is an open access peer review report distributed under the terms of the Creative Commons Attribution License, which permits unrestricted use, distribution, and reproduction in any medium, provided the original work is properly cited.

\section{Matthew A. Bowker}

School of Forestry, Northern Arizona University, Flagstaff, AZ, USA

I reviewed Effect of microalgae application on soil algal species diversity, cation exchange capacity and organic matter after herbicide treatments by Hastings et al. I believe that I have an appropriate levels of expertise to determine whether or not it meets an acceptable scientific standard. This study adds a proprietary algal amendment to agricultural soils prior to cropping and measures changes in $\mathrm{pH}, \mathrm{Om}, \mathrm{CEC}$, and the algal-cyanobacterial community. While the idea is interesting, and there is a long history of research on algal or cyanobacterial soil amendments, I cannot recommend this work due to various flaws, some rather severe. 


\section{Major comments:}

1. Most problematic is that the experimental design is unreplicated. The algal product is added to 4 plots at different rates, with a $5^{\text {th }}$ plot used as a control. Each plot has a high and low $\mathrm{pH}$ region. Measurements are conducted after application and again after 2 months. This would have been a much better designed experiment if there was at least some minimal replication (e.g. 3 plots of each type). The lack of replication really precludes most statistical analyses except perhaps for a before-after paired T-test analysis, and it is unclear to what degree apparent treatments differences arise simply because all of the plots are a little different in, e.g. pH.

2. The formulation of hypotheses is weak regarding $\mathrm{OM}, \mathrm{CEC}$ and $\mathrm{pH}$. They can be inferred but are not stated. Also, the authors state that the primary purpose was to determine if the algal suspension improved species diversity of microalgae. Since this is obviously an applied study, readers will wonder why this is a goal worth attaining....isn't the purpose of a soil conditioner the improvement of soil properties in a way that favors crop yield? Why would farmers care if there is more algal diversity in their soils?

3. Figure 3 does not illustrate species diversity, it illustrates the proportion of isolates from the plots that fall into the broad taxonomic groupings of chlorophyte, cyanobacteria, and diatom. This may be related to evenness, but there is never any presentation of data on richness, so statements about diversity seem off target.

4. Either the soil sampling technique is inadequately described or it is flawed. I understood that only 1 gram of soil was sampled from each plot, presumably a single sample due to its size. A superior sampling strategy would be to collect soil from multiple locations across the plot, pool and homogenize them, then conduct measurements on soil from the mixture. We cannot understand what is happening in an agricultural field based on $1 \mathrm{gram}$ of soil from a single point in a heterogeneous field.

5. Statistical analysis leaves much to be desired due to the experimental design. Before-after paired T-tests are used to detect changes in OM, pH or CEC. Presumably the authors included only the 4 plots amended with algae for this comparison. In doing this, the authors are ignoring their own design which amends algae at different rates, and it's not clear how the control is used if at all. Also there are many reasons besides algal addition that properties of the field would change, notably the growth and harvest of a corn crop....how can they be distinguished?

6. Presumably the algae were grown in a medium of some kind containing nutrients. Are they applied in a suspension of this medium? If so, how are effects of the algae separated from effects of the medium. A better design would also have a treatment applying the product autoclaved \& filtered so that the effects of the medium alone without the algae.

7. Table 2 is really not conducive to detecting any patterns in the data.

8. The discussion claims that the algal amendment had positive effects on the soil environment. The data presented do not support this interpretation. Again, it is difficult to know if these patterns mean anything given the experimental design, but I see: in high $\mathrm{pH}$ soils there is an ambivalent effect on OM compared to controls, in low pH soils there is no 
difference in CEC among controls and amended plots, in high pH soils some algal-amended plots have higher CEC, and some have lower CEC compared to controls, and in high pH soils some algal amendment rates increase $\mathrm{pH}$ (in contrast to what the authors state in the abstract). I just don't see evidence to support a clear argument that algal amendment improved soil properties for crops.

\section{Minor comments:}

1. Cyanobacteria are photosynthetic bacteria, not algae. If you plan to use the term algae to collectively include cyanobacteria, provide a definition. For example:....eukaryotic algae (chlorophytes and diatoms) and cyanobacteria (hereafter collectively referred to as "microalgae").

2. In the introduction, the authors state that the use of microalgae has recently been suggested in a paper from 2012. I don't doubt that this is true, but the statement implies that this is a new idea. It is not. See Singh RM (1950).

3. Define the V4 \& V5 stages

Competing Interests: No competing interests were disclosed.

I confirm that I have read this submission and believe that I have an appropriate level of expertise to state that I do not consider it to be of an acceptable scientific standard, for reasons outlined above.

Author Response 03 Feb 2015

Maria McLeod, Integrated Life Sciences Research Complex at Global Organics, Goodyear, USA

We are grateful the reviewer has taken the time to read and comment. Our responses to the comments are found below.

\section{Major comments:}

1. "Most problematic is that the experimental design is unreplicated. The algal product is added to 4 plots at different rates, with a 5th plot used as a control. Each plot has a high and low pH region. Measurements are conducted after application and again after 2 months. This would have been a much better designed experiment if there was at least some minimal replication (e.g. 3 plots of each type). The lack of replication really precludes most statistical analyses except perhaps for a before-after paired T-test analysis, and it is unclear to what degree apparent treatments differences arise simply because all of the plots are a little different in, e.g. pH."

We were also concerned with the experimental replications as they were not feasible and for that reason it was decided that the study would focus on planting 4 rows per plot and taking 6 random samples from each plot to account for the nonhomogeneity of the soil. Each plot was 0.5 squared acres. A total of 4 plots were used per treatment (one low $\mathrm{pH}$, one high $\mathrm{pH}$ ) plus one control. The total land used for this 
study was: 2.5 squared acres or $10,117.14 \mathrm{~m}^{2}$ equivalent to the area of 2 American football fields with a plant population of over 30,000. While replication of plots would have been ideal, it was not feasible or cost effective. Therefore 6 samples were taken from each plot for comparison purposes including those from a plot planted the previous year. This would be the equivalent of planting 6 smaller plots within the same area. In terms of comparison, the low $\mathrm{pH}$ and high $\mathrm{pH}$ regions were compared separately due to the non-homogeneity of the soil.

2. The formulation of hypotheses is weak regarding OM, CEC and $\mathrm{pH}$. They can be inferred but are not stated. Also, the authors state that the primary purpose was to determine if the algal suspension improved species diversity of microalgae. Since this is obviously an applied study, readers will wonder why this is a goal worth attaining....isn't the purpose of a soil conditioner the improvement of soil properties in a way that favors crop yield? Why would farmers care if there is more algal diversity in their soils?

The hypothesis was stated as two separate objectives. These can be read in the introduction: "The first objective of this study was to determine the effects of the application of a commercial proprietary suspension of microalgae (Chlorella sp. $1 \times 10$ e 3 cells per $\mathrm{mL}$, Nannochloris sp. $1 \times 10$ e 3 cells per $\mathrm{mL}$, Scenedesmus $\mathrm{sp} .1 \times 10 \mathrm{e} 3$ cells per $\mathrm{mL}$ ) formulated to provide nutrients to indigenous soil microorganisms and facilitate microbial density and diversity, as well as to increase soil carbon." "The secondary objective of this study was to determine the effects of GOgreen ${ }^{\mathrm{TM}}$ on $\% O M$ and CEC in experimental plots with different $\mathrm{pH}$ and to compare them with those obtained without GOgreen ${ }^{\mathrm{TM}}$ treatment."

As stated in the manuscript: "The results presented in this manuscript demonstrate that treatment with GOgreen ${ }^{\mathrm{TM}}$ has significant and measurable effects on soil OM content, $\mathrm{CEC}$, pH and microalgae species diversity suggesting positive effects of this formulation on soil conditions, making them more suitable to sustain crops."

We are working on a second publication that will cover the effects of GOgreen ${ }^{\mathrm{TM}}$ on crop yield.

It has been very recently demonstrated by other groups of investigators that microalgae are able to fix nitrogen in the soil and that cyanobacteria improve nitrogen $(\mathrm{N})$, phosphorus $(\mathrm{P})$, potassium $(\mathrm{K})$, iron $(\mathrm{Fe})$, and other mineral content in soil and facilitate better use of such minerals in plant growth promotion for enhanced crop production (Kumar et al., 2015).

3. Figure 3 does not illustrate species diversity, it illustrates the proportion of isolates from the plots that fall into the broad taxonomic groupings of chlorophyte, cyanobacteria, and diatom. This may be related to evenness, but there is never any presentation of data on richness, so statements about diversity seem off target.

Species diversity is by definition a measure of the diversity within an ecological community that incorporates both species richness (the number of species in a community) and the evenness of species' abundances or simply stated, "the number 
of different species that are represented in a given community (a dataset)". The pie charts on figure 3 showed species diversity as total counts of species per group and it is clearly seen from the chart that the number of species within each category varied with treatment when compared to the untreated controls.

4. Either the soil sampling technique is inadequately described or it is flawed. I understood that only 1 gram of soil was sampled from each plot, presumably a single sample due to its size. A superior sampling strategy would be to collect soil from multiple locations across the plot, pool and homogenize them, then conduct measurements on soil from the mixture. We cannot understand what is happening in an agricultural field based on 1 gram of soil from a single point in a heterogeneous field.

As stated in the manuscript, the protocols followed were those implemented by the Irrigation Research Foundation (IRF). Their protocols indicate taking 6 different samples from different places in the plot for analysis. This is the protocol followed in this study.

5. Statistical analysis leaves much to be desired due to the experimental design. Before-after paired T-tests are used to detect changes in OM, pH or CEC. Presumably the authors included only the 4 plots amended with algae for this comparison. In doing this, the authors are ignoring their own design which amends algae at different rates, and it's not clear how the control is used if at all. Also there are many reasons besides algal addition that properties of the field would change, notably the growth and harvest of a corn crop....how can they be distinguished?

All plots were included in the comparison. Due to the heterogeneity of the soil, a "before and after" comparison seems more representative of treatment especially because the controls were also heterogeneous when compared to the plots. A comparison between different doses only showed one characteristic worth annotation. This result is and was mentioned in paragraph 3 of page 9: "At this $\mathrm{pH}$, treatment with GOgreen ${ }^{\mathrm{TM}}$ the previous year (plot 3) and with twice the recommended application rate (plot 4) resulted in a pH increase of 0.2 units two months after harvest when compared to the other plots." As growth and harvest and the influence of GOgreen ${ }^{\mathrm{TM}}$ on corn are of interest to readers, these findings will be discussed in detail in the following manuscript. Readers who would like more information on harvest and yield resulting from these studies, (before the second publication is available online) are invited to contact the authors directly.

6. Presumably the algae were grown in a medium of some kind containing nutrients. Are they applied in a suspension of this medium? If so, how are effects of the algae separated from effects of the medium. A better design would also have a treatment applying the product autoclaved \& filtered so that the effects of the medium alone without the algae.

Yes, as the third paragraph of the introduction stated: "The first objective of this study was to determine the effects of the application of a commercial proprietary suspension of microalgae (Chlorella sp. $1 \times 10$ e 3 cells per $\mathrm{mL}$, Nannochloris sp. $1 \times 10$ e 3 cells per $\mathrm{mL}$, Scenedesmus sp. $1 \times 10$ e 3 cells per $\mathrm{mL}$ )". Since the product is sold 
as a commercial suspension, the product was applied in the same way a farmer would apply it after purchasing it. Autoclaving the product would have been detrimental to the live algae defeating the purpose of the study.

7. Table 2 is really not conducive to detecting any patterns in the data.

As the title indicates, table 2 describes "Treatment and applications for plots 1-4 and control during 2011". There was no intention to provide patterns in the data for this table.

8. The discussion claims that the algal amendment had positive effects on the soil environment. The data presented do not support this interpretation. Again, it is difficult to know if these patterns mean anything given the experimental design, but I see: in high $\mathrm{pH}$ soils there is an ambivalent effect on OM compared to controls, in low pH soils there is no difference in CEC among controls and amended plots, in high $\mathrm{pH}$ soils some algalamended plots have higher CEC, and some have lower CEC compared to controls, and in high $\mathrm{pH}$ soils some algal amendment rates increase $\mathrm{pH}$ (in contrast to what the authors state in the abstract). I just don't see evidence to support a clear argument that algal amendment improved soil properties for crops.

CEC and $\mathrm{OM}$ are closely related to $\mathrm{pH}$. Cation exchange is $\mathrm{pH}$ dependent by definition. Different crops require different $\mathrm{pH}$ values and different types of soil exhibit different CEC. As stated in the objectives, the purpose of this work was to show that it is possible to affect CEC and OM as well as $\mathrm{pH}$ when a live microalgae suspension is applied to the soil. The $\mathrm{pH}$ requirements for a particular type of soil Minor comments: would help a farmer make a decision regarding product use and timing.

1. Cyanobacteria are photosynthetic bacteria, not algae. If you plan to use the term algae to collectively include cyanobacteria, provide a definition. For example: ...eukaryotic algae (chlorophytes and diatoms) and cyanobacteria (hereafter collectively referred to as "microalgae").

We agree with the reviewer. Prior to the use of molecular biology for identification, cyanobacteria were formerly called blue-green algae because they are photosynthetic and aquatic. We appreciate the comment and would like to clarify that we were unable to find the term Cyanobacteria associated with the term blue-green or algae in our write up of this manuscript except for text referenced from publications that are over 10 years old.

2. In the introduction, the authors state that the use of microalgae has recently been suggested in a paper from 2012. I don't doubt that this is true, but the statement implies that this is a new idea. It is not. See Singh RM (1950).

We were unable to find Singh RM in references related to microalgae from 1950. We would appreciate it if the reviewer could provide the complete reference.

3. Define the V4 \& V5 stages 
We were unable to find V4 in the document. We were able to find V5 in a phrase on the first paragraph of page 4 as "V5 stage of plant growth as well as 4, 6, 7, and 8 weeks after emergence". The term refers to a stage of plant growth. Leaf stages are usually described as "V" stages. V5 stage of plant growth is defined as the stage where the collar of leaf number 5 is visible.

Once again, we would like to thank the reviewer for taking the time to read our manuscript and we respect the opinions expressed.

Competing Interests: No competing interests were disclosed.

The benefits of publishing with F1000Research:

- Your article is published within days, with no editorial bias

- You can publish traditional articles, null/negative results, case reports, data notes and more

- The peer review process is transparent and collaborative

- Your article is indexed in PubMed after passing peer review

- Dedicated customer support at every stage

For pre-submission enquiries, contact research@f1000.com 